\title{
Paleoenvironmental reconstruction of an urban archaeological of Jurash, Southwest of Saudi Arabia
}

\author{
Mena Elassal \\ Assistant Professor, Geomorphology and \\ Geoarchaeology, Faculty of Humanities \\ King Khalid University, KSA.
}

Received on $8 / 10 / 2019$

Accepted on 3/2/2020 
PALEOENVIRONMENTAL RECONSTRUGTION OF AN URBAN ARCHAEOLOGICAL OF JURASH, SOUTHWEST OF SAUDI ARABIA. Mena Elassal

\author{
Assistant Professor, Geomorphology and \\ Geoarchaeology, Faculty of Humanities \\ King Khalid University, KSA.
}

\section{Abstract:}

Jurash is located in the governorate of Ahad Rufaida, $15 \mathrm{~km}$ south of Khamis Mushait, which is part of Asir region in the southwest of Saudi Arabia. The site contains the remains of large buildings, some of them are of stone and some of clay, and dates back to the pre-Islamic period and successive Islamic periods that indicate the human settlement in the city. Where the city of Jurash is located on the trade route and the next pilgrimage from Yemen, and thus became an important commercial center at that time. Hence, the importance of the study in redrawing the maps of the city and working on an ecological perception that highlights the urban development and the old environmental conditions and determining the archaeological value of the city of Jurash because of its geographical (natural / human) and tourism investment. This will enable the orienting of the future course of the city and the appreciation of its heritage as well as the study of the archaeological and archaeological value of Jurash and its possibility of being included in the list of World Heritage sites. This will also enable obtaining physical evidence to prove the heritage value and tourism importance of the city and its economic role in achieving the Kingdom of Saudi Arabia Vision 2030.

Pedostratigraphy applied to urban archaeological sites, combined with geomorphological and archaeological data, provide important information for interpreting the complexity of urbangeoarchaeology areas and their environment.
This paper applies this methodology in the case of Jurash city and presents geomorphological and geoarchaeological data (stratigraphy, physicochemical soil properties, radiocarbon dating and pottery) for the study area where these remains are located. Geoarchaeological work is essential in archaeological excavations of urban areas, as demonstrated at Jarash where the study of pedostratigraphy provides crucial information on past environmental changes and human activities. Pedostratigraphic records and archaeological remains should be considered part of the geological and cultural heritage of urban areas.

Keywords: Paleoenvironmental, urban geoarchaeology, Jurash.

\section{Introduction:}

The application of geoscience to archaeology provides a great deal of information regarding past human activity and the environmental context of archaeological sites. The constant evolution of cities guarantees the fact that they host a multitude of archaeological remains (be they of urban origin or not), which over the course of time, may become features of the modern city if they are adequately managed and protected. Asir region was known for its ancient roles in makhlef. Jurash is located in Asir region and it gained economic importance due to its location along major trade routes. Trade commodities included agricultural products such as fruits, grains, and vegetables, in addition to industrial products such as weapons, leather, and minerals. Jurash is entirely artificial after successive stages of archaeological mission, and the construction of a wall around the rest of the old city masking the natural configuration of the city. The scarcity of paleoenvironmental and archaeological data does not allow the position and configuration of throughout the ages to be established to any degree of precision. Although 
their reliability is variable, the use of historical maps and aerial images is a common approach in reconstructing the natural configuration of Jurash city. However, it is possible to obtain information from19th century maps produced, if the configuration of sedimentary bodies reflected in the photos are natural. In addition, where it lies between the mountain of Hammam in the east, and on the west basin Wadi Bisha to benefit from the floods, which is thus characterized by its location strategic.

Geoarchaeology applies knowledge and techniques from different earth science disciplines in order to resolve historic-archaeological problems (Bennedetti, Cordova, \& Beach,2011, p.85; Butzer,1982; Canti\& Huisman, 2015, p.96; Nicoll\& Murphy, 2014, p. p1-4; Panin\& Bronnikova, 2014, pp,1-5). and is directly linked with paleoenvironmental reconstruction in archaeological contexts (Dincauze, 2000). A main focus of geoarchaeology is the study of urban areas as they often have a higher degree of complexity in comparison with more rural settlements (Rothschild\& Dizerega, 2008). Indeed, a geoarchaeological approach can be highly informative for understanding urban processes, demographic cycles, and the intersection between sites and their surrounding landscapes (Butzer, 2008).

Since the establishment of the General Authority for Tourism and National Heritage in 2000, Saudi Arabia has sought to facilitate the aggressive development of tourism at the national level. The efforts so far are likely to bring about massive tourism expansion in the upcoming years. Development in the Saudi tourism sector has rather focused on areas of high potential to be mass markets, i.e., sites of natural beauty and mild climate.

However, the impact of tourism development on the environment has not been properly assessed
(Briassoulis, 2000). Tourism activities have already resulted in degradation of the natural resources on which the industry depends. The National Commission for Wildlife Conservation and Development (NCWCD) was created in 1986 to manage wildlife reserves (Seddon \& Khoja, 2003). Due to their natural elements, good infrastructure, hospitality and historic sites, regions included in the National Tourism Plan, such as Asir region, have become tourist destinations on national and international scales. Domestic tourism has soared in the recent years. Asir is now considered as the main tourist attraction in the Kingdom of Saudi Arabia. Hundreds of local, Arab and international tourists annually visit the region. Asir is currently one of the most popular tourist destinations in the Arab World and has been selected to be the Capital of Arab Tourism in 2017 (Arab Tourism Organization, 2015). Therefore, we must preserve and value the heritage in Asir region shedding light on its historical importance throughout the ages and historical periods.

\section{The Studied Area:}

Jurash is located in the governorate of Auhd Rufida in Asir region in southwest Saudi Arabia and is located $15 \mathrm{~km}$ south of Khamis Mushait. Jurash archaeological site in between of Mount "Hamouma" and Jabal "Shukr". The site contains the remains of large buildings, some of the stones and other clay and contains the prehistory dating back to the pre-Islamic period and successive periods until the eleventh century $\mathrm{AD}$, where there were indications of settlement during the Abbasid period in the north and center of the site, and in the south of the site. There are signs of settlement during the middle and late Islamic period. Jurash is located on the pilgrimage road coming from Yemen. It was famous for its leather and war industries. Jurash was also known during the period of the Prophet's mission as an important 
commercial center. Jerash is important because it is located on the commercial road, which connects the kingdoms of southern Arabia its north. Its geographical location is of great importance, for the remaining settlements and cultural centers in this part of the Arabian Peninsula, because its commercial center serves a wide area. It extends from Najran in the south to the ends of the borders of the north region of Asir, and from Tathlith in the east, to the Red Sea coasts in the west. Old sources are not remembered and there is no commercial center in this region comparable to Jurash, which confirms that it was the main center, which starts from its commercial transactions, to the rest of the local markets during the era of the Arab kingdoms. (Al- Ghamedi,1996, p.408) fig. (1) location of study area.

\section{3- Results}

\subsection{History}

Jurash containing that archaeological site date back to BC and the Islamic era. It is noteworthy that the excavations revealed ancient monuments dating back to 3,000 years and have illustrated the features of an Islamic civilization in the existence of two mosques. The excavations were performed by a joint Saudi-American team. The Saudi team has completed the site exploration since $1431 \mathrm{H}$ until now, producing significant results. For the archeological site of Jurash, it is one of the most important sites in the history of the Arabian Peninsula a part of the architectural unit was detected with thick walls built using large stone blocks, which is likely to have been a part of a fortress or a temple dating back to a period before Islam. It had been used during the early Islamic

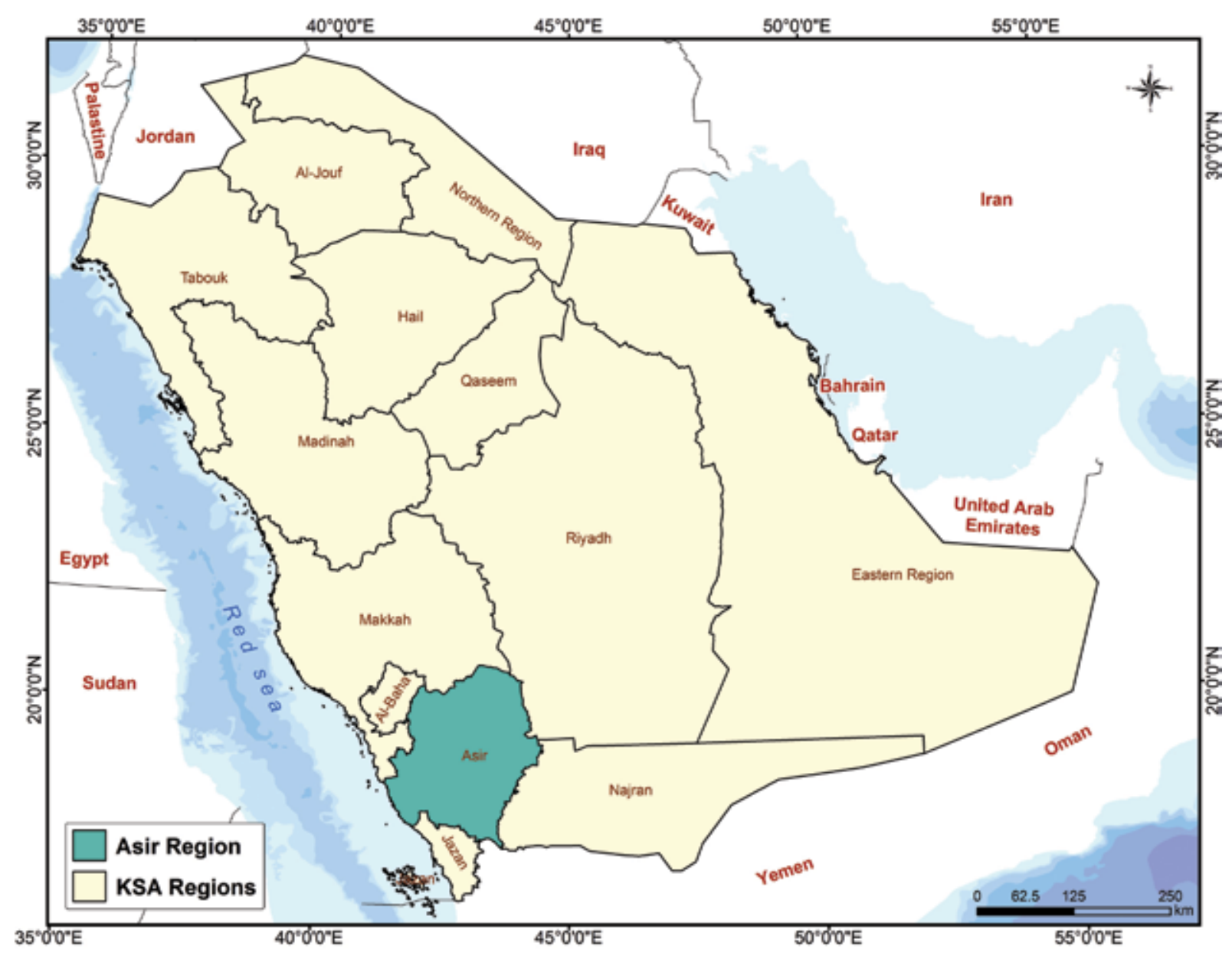

Fig. (1) The location of study area. 
period, and it had seen some modifications and additions. It was mentioned that Jurash was in historical sources, as the traveler (Arab Hamdani $945 \mathrm{~m})$. In that way, incense trade in ancient times south of the Arabian Peninsula to the Mediterranean Sea, has passed through the first millennium Jurash BC. Jurash is one of the most important sites on the road to the ancient caravan. Jurash, near Abha in the southwest Asir region is one of the most important archaeological sites in the history of the Arabian Peninsula, with excavation teams unearthing relics dating back thousands of years. It was famous for manufacturing weaponry, including catapults and war machines that could be described as tanks, as well as being a rest stop and meeting point due its trade route location. Jurash was an important city in the pre-Islamic era playing a cultural and economic role due to its industries, and the Saudi Commission for Tourism and National Heritage (SCTH) has been exploring the area for almost a decade. Lion pouncing on a bull found in Jurash are proof of the city's ancient past.

Historical and archaeological sources showed that Ahad Rafidah and the area around it were known as Mikhlaf Jurash. Jurash ruins were still visible in Ahad Rafidah city even now, "based on early sources, the number of industries was limited. The leather industry flourished greatly and Abu'l-Fida and Ibn Al-Mujawir talked about this industry's good quality that helped it become famous outside the Arabian Peninsula, until this leather became famous in foreign markets such as Iraq, Persia, the Levant and others." Mikhlaf Jurash was renowned for imanufactured tanks: Wooden machines covered with cowhide that men would ride near besieged fortresses. Wealthy citizens from Makkah, Taif and elsewhere in the Arabian Peninsula flocked to Jurash to learn about these goods so they could protect themselves and their assets.
There werefigures from the Prophet Muhammad's time (peace be upon him), Urwah ibn Mas'ud and Ghailan ibn Salamah, who lived in Jurash to learn about catapults and tanks during the siege of Taif, reinforcing the city's historical significance (Bin Jurais, 1998, p.68).

Hamwi has stated that Jurash from Mikhalev Yemen. On the one hand, Mecca is in the first region. It is the length of 65 degrees and width of 17 degrees (Hamwi, 1906, p.127). Thus, it is an area of about almost $122.655 \mathrm{Km}^{2}$, and currently, an area of about $81000 \mathrm{Km}^{2}$. The area of Mikhlaf Jurash was the largest area of Asir region now about almost $41655 \mathrm{Km}^{2}$. The boundaries of Mikhlaf Jurash were vast, including Asir and Al Bahah regions. Located north of Najran and south of Mecca, Mikhlaf Jerash was the area currently occupied by the military city in Khamis Mushayt and its surrounding areas. It is now the archaeological site of Jurash area. Fig. (2) Border of Jurash.

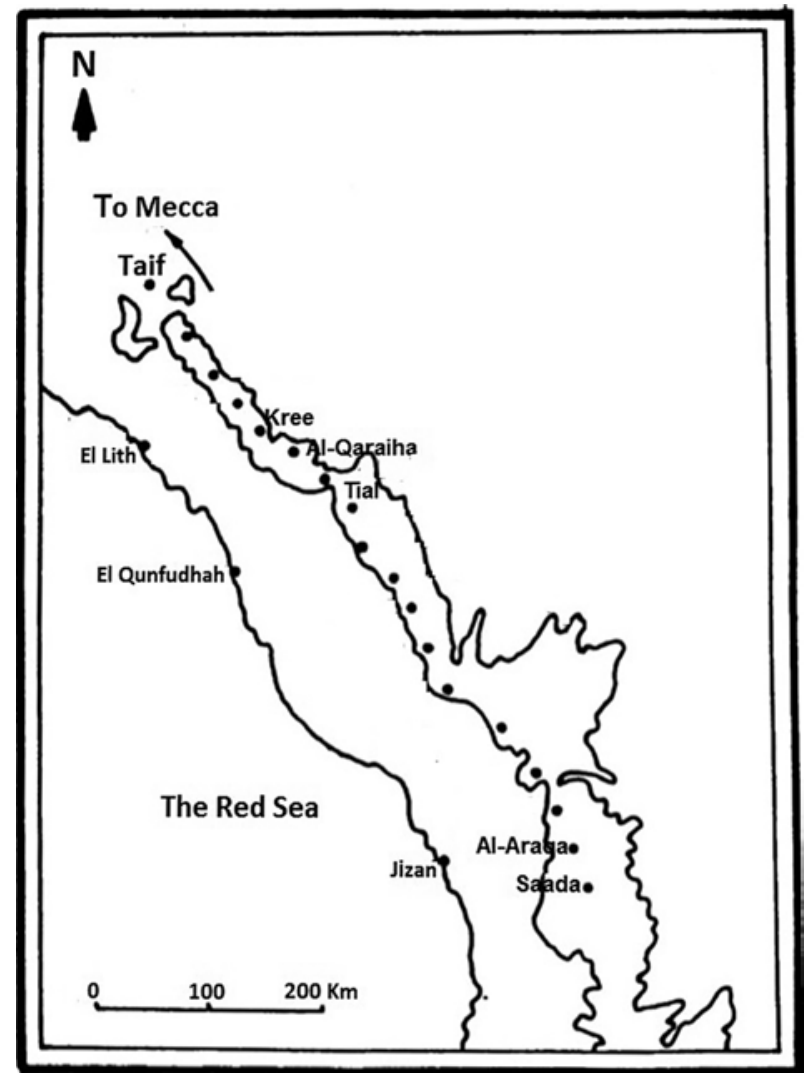

Modified:( Grace, 1998, p.70).

Fig. (2) Border of Jurash. 


\section{3-2 Geology}

The Arabian Shield represents the geological basis of the Asir region, of which Jurash is part. It is an ancient land mass formed from rocks igneous and metamorphic, which dates back pre-Cambrian era. It is spread by basalt, which dates to the Triennial and Quadratic periods. and is covered by sedimentary rocks of Paleozoic periods, in addition to the sediments of the valleys where the study area passed on a very a complex geological history of severe folding and cracking (Al-Walya'i, 1997, p.30). The area has several mountainous volcanic peaks, which consist mainly of granite rocks, and are covered by basalt blocks. There is Wadi Bisha which is covered with gravelly soils and rock spasms (Abu al-Ela, 1975, p. 19) fig. (3) Geological map.

\section{3-3 Geomorphology}

Haton explained that "the present is the key to the past" (Abu al-Enein, 1981, p. 36). Jurash are characterized by low slopes passing laterally to a flat plain, which flanked several mountainous volcanic, from rocks igneous and metamorphic, which dates back pre-Cambrian era. It dates to the Triennial and Quadratic period during which the city was built. The study area is characterized by its appearance Mountain. It is one of the most Saudi Arabia regions, complex, high and diverse geomorphological features the various geomorphic units and their component were identified and mapped. The descriptions of different geomorphic units of study area are given below. The study area can be divided into three main morphological units, each with distinct geomorphological characteristics fig. (4):

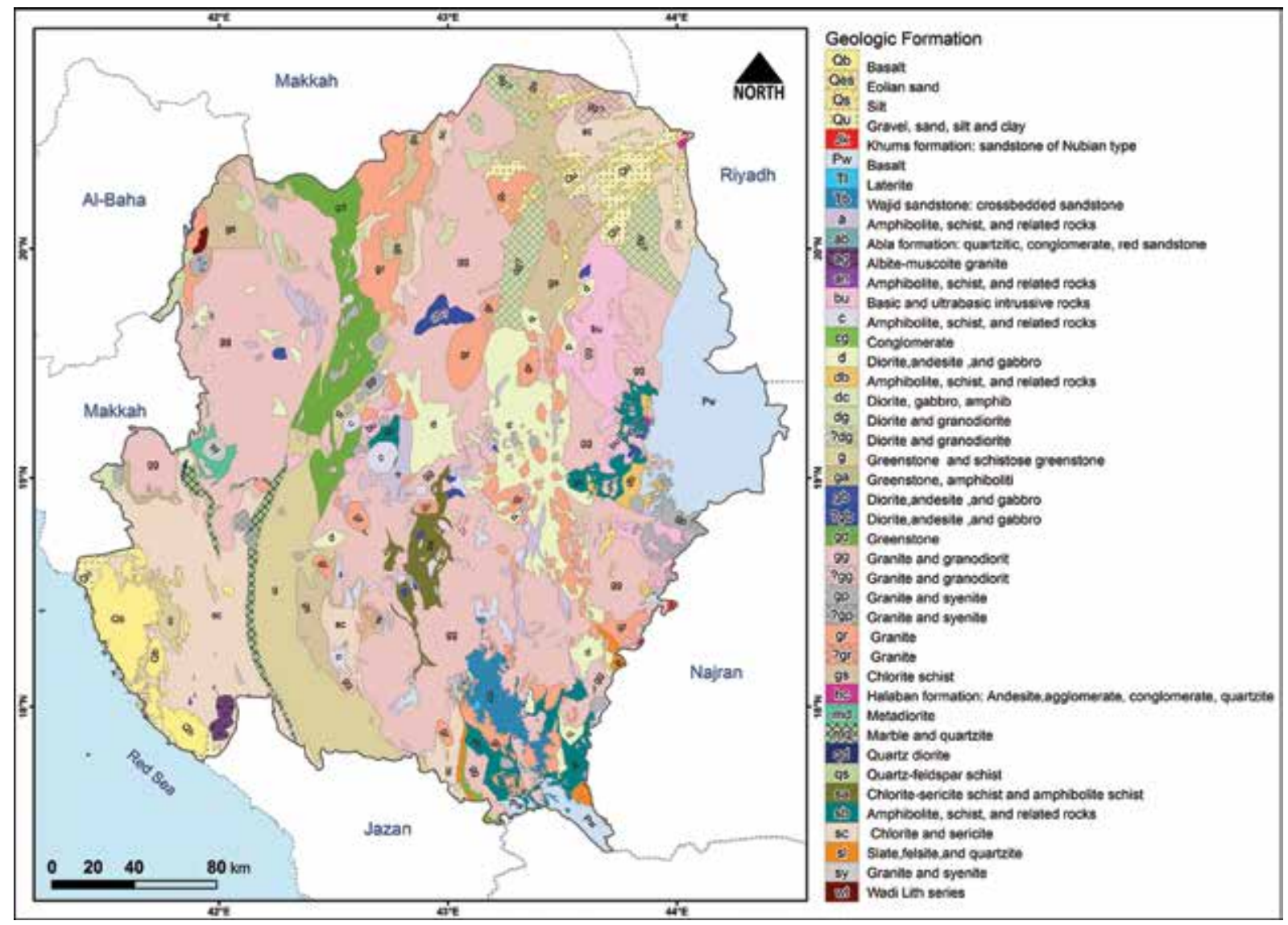

Fig. (3) Geological map of the study area 


\section{1- Red Sea coast area, known as Tihama plain.}

It is known as a Tihama Asir, narrow coastal plain. It is a specific geomorphological unit which consists some of basaltic flows and cones of volcanic ash materials, and the tongues of the aharat (Habib, 2005, p.9). On the Tihama Plain spans range of Parallel valleys, which descending from the mountains of Sarwat Such as the valleys of (Bish, Jizan and Sabia) and other short and fastflowing valleys. It contains dry and wet sabkha, some of the high hills, Sand dunes, and deposits of lime and salt (Al-Sharif, 1984, p.41).

\section{2- Mountain range}

The mountain range extends from north to south, adjacent to the Red Sea, known as the Asir Mountains. The mountains descend rapidly and suddenly towards the west to Red Sea coast and descend gradually towards the east. The mountains range a height of from 1500 meters to more than 3,000 meters. This elevation exceeds some of the high mountain peaks, such as the "Souda" mountain, 3015 meters above sea level. The highlands of the mountain range are waterdividing areas for valleys draining into direction east and west (Al- hidab, 1992, pp. 10-11).

\section{3- Plateaus and Piedmont range:}

This range is the northern and eastern parts of the study area. This range represents the transition zone between the mountain range, known as the Piedmont range or the range of the mountain feet. This range is the sedimentation surface of the valleys and the spherical fans consisting of gravel, glamide, rock masses and sand. The surface of the scale is characterized by the relative flat and gradient of the gradient from west to east. It is characterized by a strong separation due to tectonic movements. Floodplains, Rocky hills, Rock outcrops, volcanic cones, and Isenberg (AlKoumi, 2004, p. 1455).

\section{3-4 Geoarchaeology and stratigraphic features:}

The geographic location that Jurash has enjoyed has created a strategic position, both in the economic or political, making it, are classified within the centers of civilization of great importance during the period from the second and the first centuries $\mathrm{BC}$ to the sixth century AD. Jurash was known in this period as one of Mkhalef Yemen, on the one hand Mecca, and it was a great city and state wide, to the upper Najd. From this definition, it indicates that Jurash was a large province, extended between Najran in the south and north of Bisha. It is currently known as the region of Asir Province (Al- Ghamedi,1996, p.410).

The wells are scattered along the road, and this is evidence that the choice of this route and its route must provide important water resources. Several stone installations were also monitored, as well as a mosque. We find that the lack of specialized sources and references, and a little written about the subject in detail, where most of the sources dominated fragments of useful information scattered here and there. The information of these geographic sources was fragmentary, not clearly indicative of the route or of determining land ownership or tribal ownership. At the beginning of the fifth century AD caravans took another route across the mountainous plateau, whose stations and houses differed from the first route between the ports of Yemen and Tabala, located in the southeast of Mecca. It seems that by the name of Dar es'ad al-Kamel, this transformation took place during the reign of King Al-Hamiri As'ad al-Kamel, who lived in the early fifth century AD. Although this road was bumpier than the first incense road across the eastern valleys, there were more water and vegetation, Abraha al-Habashi takes him in his disastrous campaign on Mecca for the great elephant's need for water and fodder (El emri, 2003), which is not available 


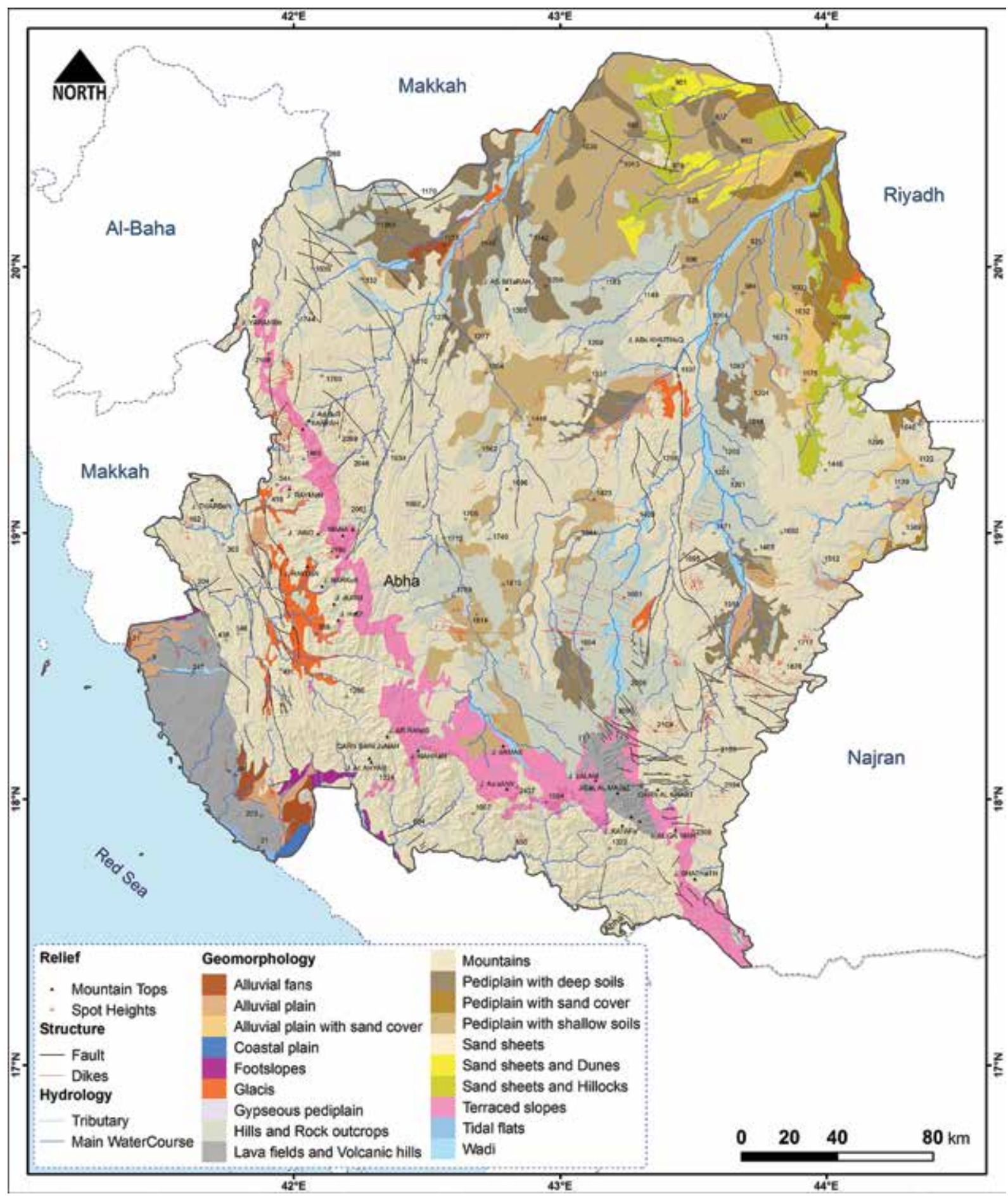

Fig. (4) Geomorphological characteristics of study area.

in road houses across the eastern valleys. This is evidence that Jurash was probably one of these stations to be located on the bank of Wadi Bisha, while the other branch of the road goes to the north-west of the Arabian Peninsula through the Thalithian valley and then deviates to the west through the eastern outskirts of Asir and may pass through Jurash near Khamis Mushayt, Fig. (5) location of Jurash. 


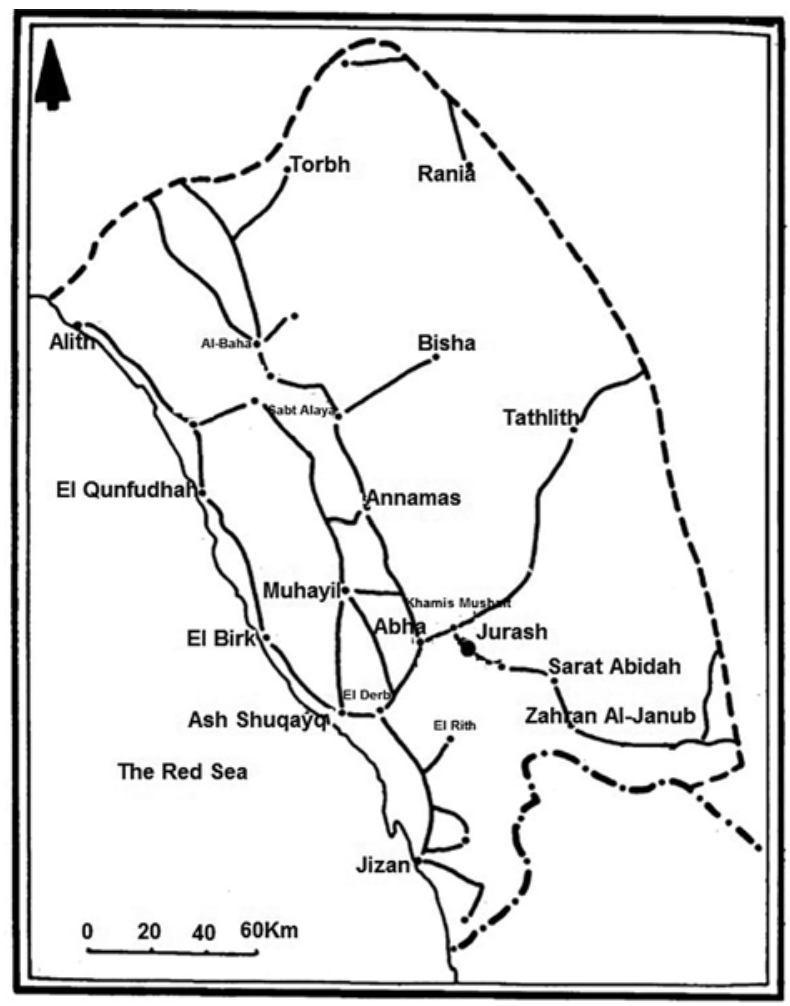

Modified: (Grace, 1998, p.70).

Fig.(5) Location of city of Jerash archaeological site.

The site of Jerash is characterized as a rectangular shape, about 1,000 $\mathrm{m}$ from north to south, and 500 meters from east to west. It extends along the north from the south to the archaeological hills. It contains a major hill, and a number of small hills concentrated density in the middle (Picture 1). On the eastern side, there are rocks of large size. The area of the site is limited due to modern urban extension. The length is up to $80 \mathrm{~cm}$ and the width to $60 \mathrm{~cm}$. During the field visit in April 2019, there was a large mosque built above a mosque below it, and they date back to the early Islamic period, built on the foundations of a fortress dating back to the period pre-Islamic (Picture 2). In addition to the inscription on the rock of a lion and a bull written down them, the predicate line of this painting was carried out by prominent engraving of molar in both the lower and upper parts, of different shapes and sizes which are carved from sandstone (Picture 3 ).

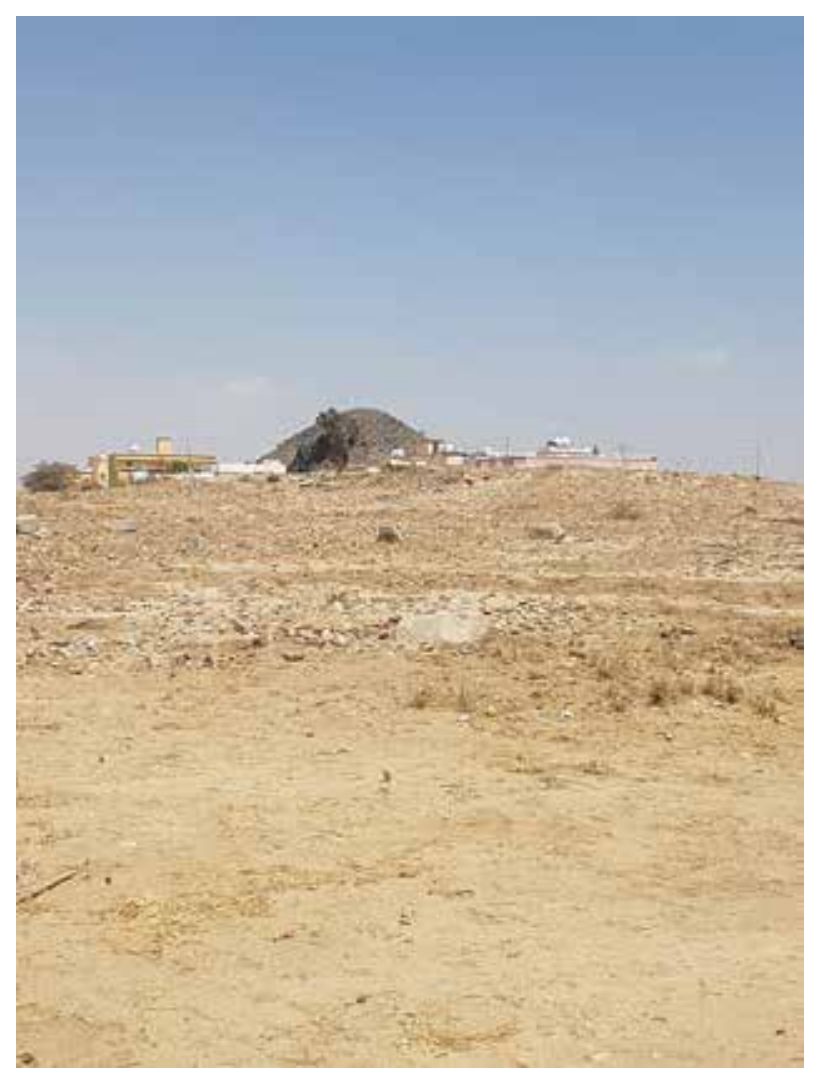

Picture. (1) The archaeological hills. 


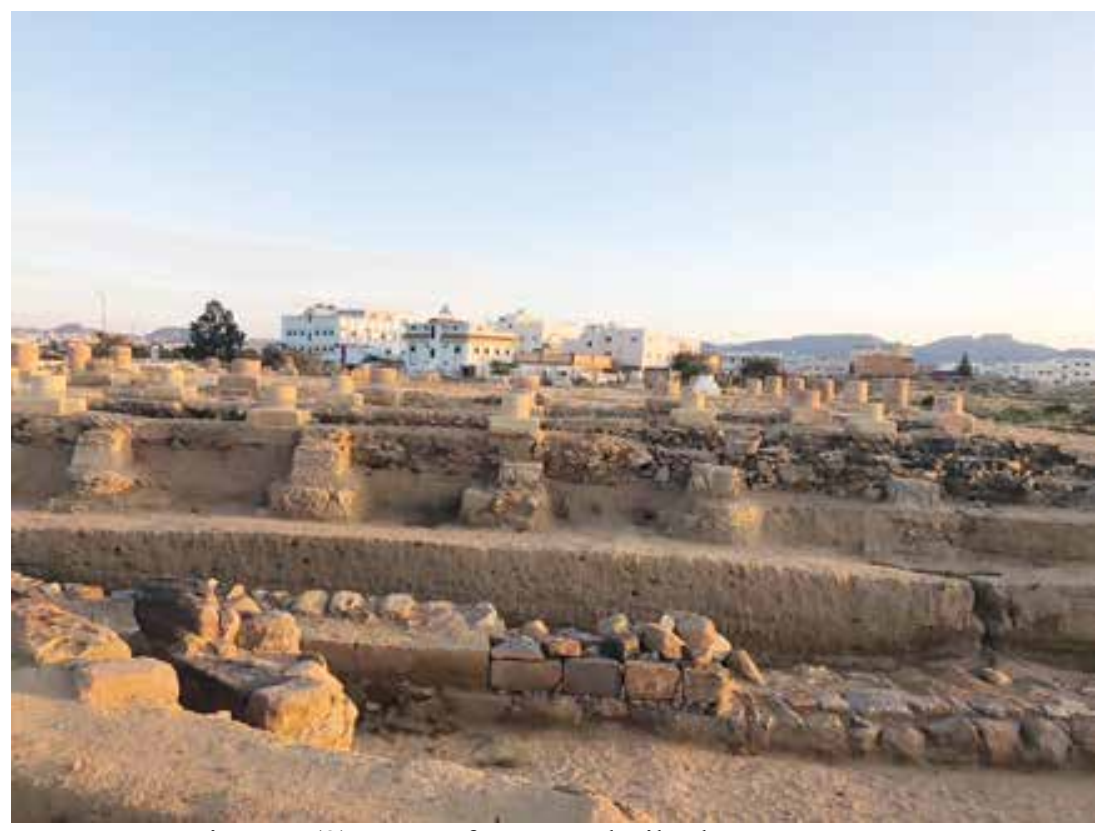

Picture. (2) Parts of mosque built above a mosque

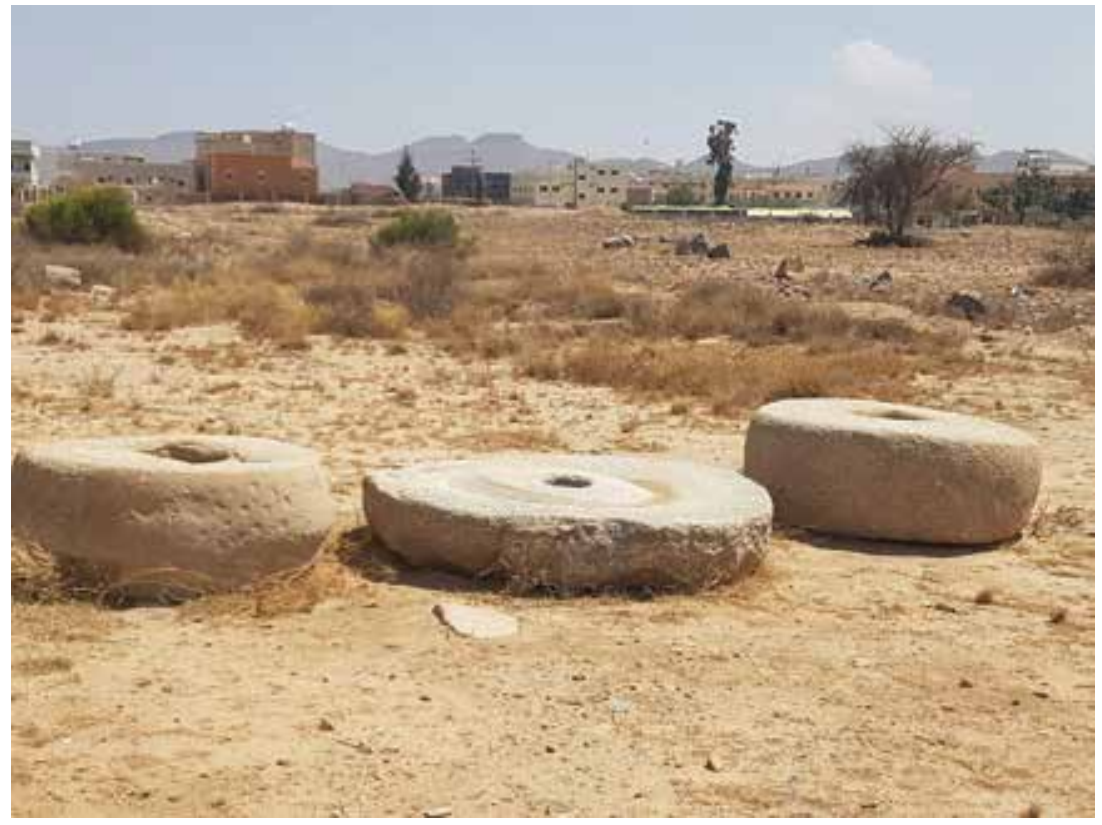

Picture. (3) Some of molars

In order to date the site of Jurash, it was based on archaeological findings such as cash currency and pottery. Cash currency is one of the most important archaeological findings which is reliable on the dates of the archaeological site. It carries historical and economic connotations. Therefore, this research has relied on a study (Al-Ghamdi, 1996, pp.439-441). It was during the drilling process that Roman coin cash which dates back to the period (211- 217 AD) have been found. It goes back to $212 \mathrm{AD}$ (Fig. 6). As a result, it emphasizes the prosperity of the land trade routes. Its arrival in Jurash was considered normal in the commercial usages. This confirms that Jurash was positioned in an economic area. Moreover, it was the station for trade exchange on old trade route. Accordingly, the sedimentation rate of Jurash could be inferred through calculating the difference between the date of drilling and the date of the Roman coin cash. It was about almost 130 $\mathrm{cm} /$ in 1784. Consequently, the sedimentation rate $0.072 \mathrm{~cm} /$ year (Fig. 7) Planning of Jurash site. 


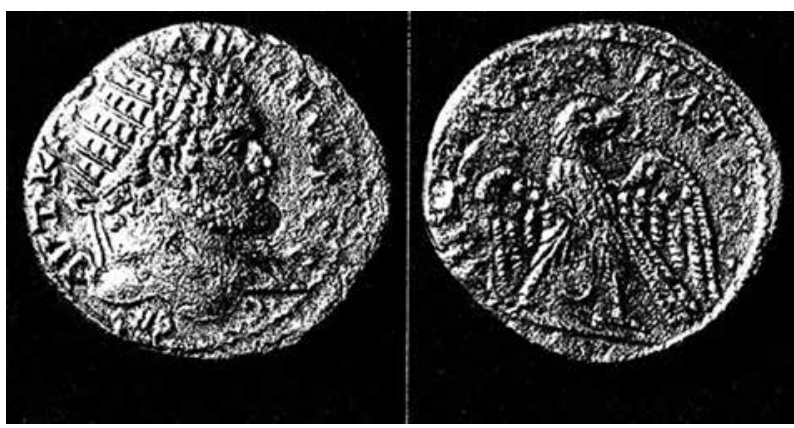

After: (Al-Ghamdi, 1996, p. 441).

Fig. (6) Roman coin cash in Jurash site.

Jurash archaeological site contains two distinct types of installations. The first is in the buildings of the huge type which contain stone foundations and built in the way of prominent parties by using the method of installation triangle angles. Five buildings of this type were found; although some have recently been exposed to some changes. The second type is characterized by the use of burnt bricks, mud and small stones. However, the damage caused to the site of the erosion factors has removed mud without affecting bricks or stones. Hence, the site seems huge of rubble and stones. Using carbon-14 method of analysis, the results show that Jurash area has witnessed a period of settlement during the first time period the B.C. Then a second period was at the beginning of the Islamic era where lower layers of soil go back to the first century AD. The fifth layer dates back to $280 \mathrm{AD}$, the fourth to $510 \mathrm{AD}$, the third to the Islamic era, and the second and first to $1030 \mathrm{AD}$ (Zairins et al, 1981, p.25).

In order to know the sequence of layers of human settlement, the soil layers of the surface were sieved, and it turns out that they date back to the Islamic era depending on the remains of the pottery. The bottom layer samples were analyzed with carbon 14, and it was found that it dates back to the third and fifth centuries AD (Graf et al, 2008, pp.31-32). The technique was selected from trench drilling Log J1 to identify the stratigraphic and morphological layers depending on extracting sections which were sampled by archaeological materials and description soil data, from bottom to top, with the aim of obtaining a high depth/ time resolution fig. (7) Planning trench and coring of Jurash site, fig. (8) Stratigraphy of Log J1.

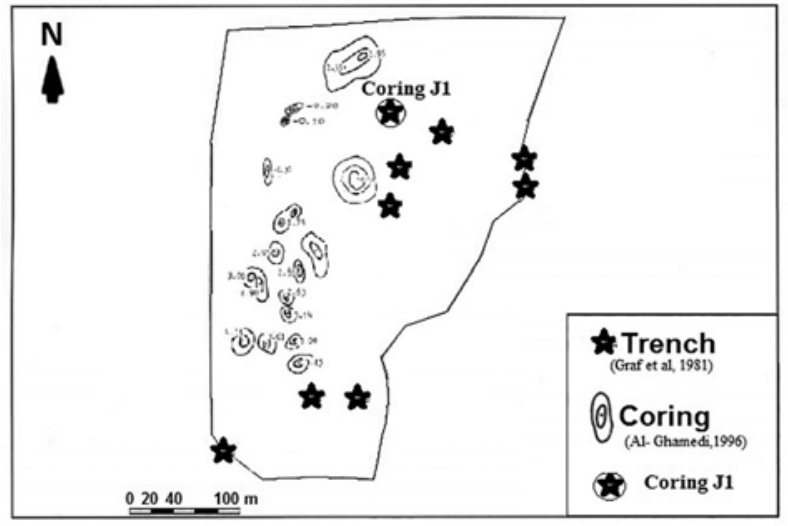

After: (Graf et al, 1981) \& (Al-Ghamdi, 1996)

Fig. (7) Planning trench and coring of Jurash site. 


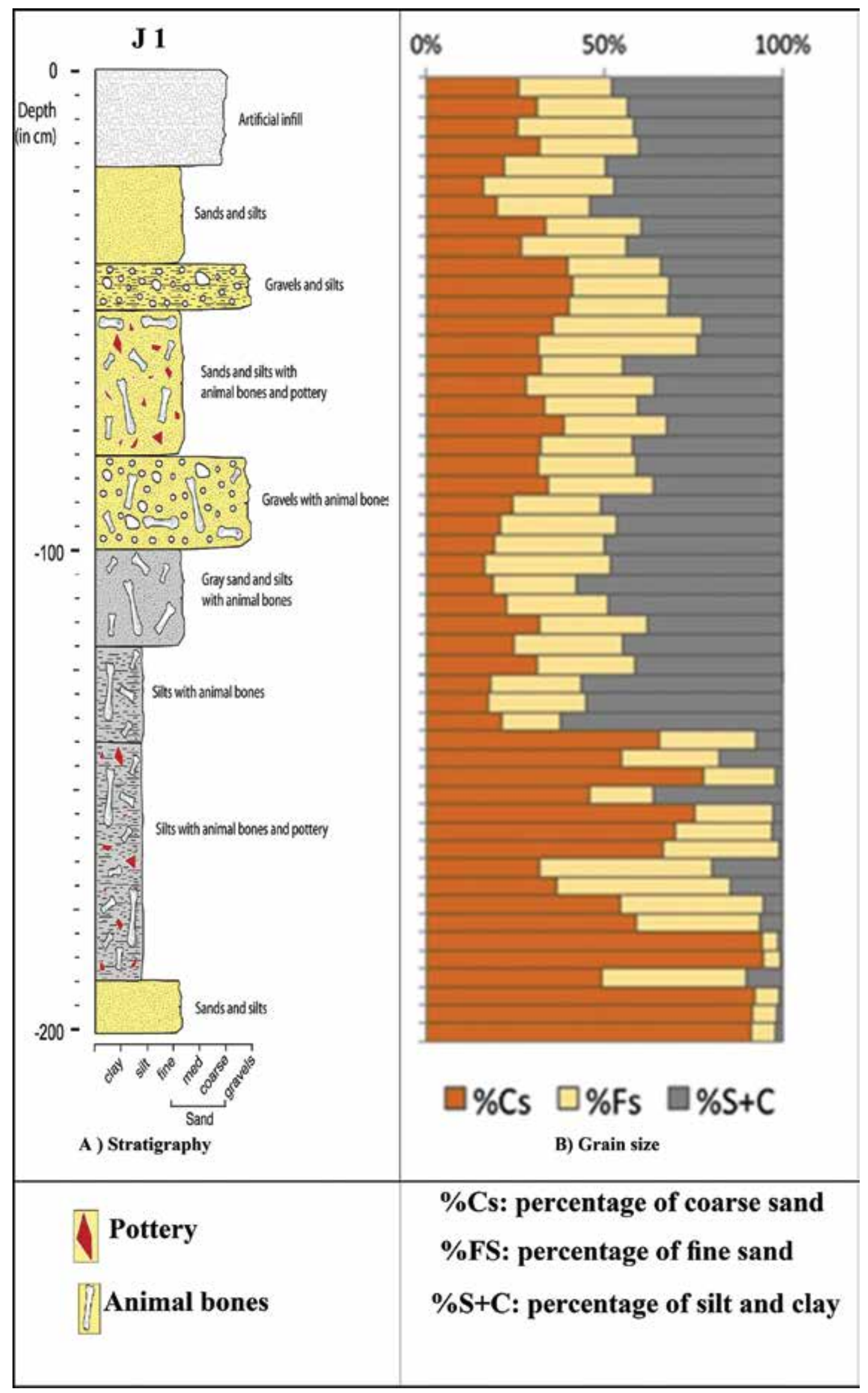

Draw: Depending on the results of the excavations, 1996.

Fig. (8) Stratigraphy of Log J1. 


\section{Conclusions:}

The paleoenvironmental record of this sedimentary sequence is highly complex and characterized, both in space and time, by deposit sand featuresrelated to humanactivities mixed with those of a natural sedimentary origin. According to Castro (2007), the archaeological data indicate that the study area from the first century BC until the eleventh century AD is, stratigraphically, an evidence that the stratigraphic records are likely contemporaneous, and the formation of the siltclay layers may have been related to human activity. Radiocarbon dating performed for this study allows a more precise chronology for the different pedosedimentary formations, integrated with archaeological data, which is able to present a chronological frame work for human activity.

Landscape evolution at Jurash was affected by urban development. Urban growth and new spatial dynamics led to a change in the position of the site relative to the city. The site once occupied a peripheral position as an agricultural land use and later became incorporated with in the city. However, this circumstance changed when remains of the site were exhumed. At this point, geoarchaeological research intervened, providing essential information about the environmental and archaeological context of the site. From this moment on, the archaeological remains took on a new meaning for the city due to the information provided about its past, with a new focus on the importance of Jurash. This discovery, without doubt, has helped to create a new vision and sense of identity for the city. This site is now integrated into the city with the Ministry of Tourism and Antiquities. Hence, this increases its value as part of the city's cultural heritage. The associated pedostratigraphic record should also be considered part of the city's geological heritage in that it provides essential information on Jurash historical environment that frames our understanding of the past. Geoarchaeology should be considered an essential part of archaeological excavations in modern urban areas for better interpretation of the rich and complex history of cities. Thus, it results in obtaining physical evidence to prove the heritage value and tourism importance of the city and its economic role in achieving the vision of the Kingdom of Saudi Arabia 2030.

\section{Acknowledgements:}

I thank Saudi commission for Tourism and National Heritage in the Abha region, and the director Mr. Awad Alqahtani of the Jurash site and his work team, for their allowed me to enter Jurash site.

\section{Arabic references:}

1- Al-Walya'i, Abdullah (1997), Climate Change in the Dry Zone: A Case Study of the Kingdom of Saudi Arabia, The Annual Geography Book, Imam Mohamed bin Saud Islamic University, Riyadh.

2- Al- Ghamedi, Abdul Kareem A.S. (1996) Analytical study of pottery samples from the Archeological site of Jurash, south west Saudi Arabia, Journal of King Saud University, Issue 8, pp. 407- 447.

3- Hamawi, Yaqoot ibn Abdullah, Dictionary of countries, First Edition, Press of Elsaida, Cairo, $1323 \mathrm{AH}, 1906 \mathrm{AD}$.

4- Joris Zairins, Abdel-Jawad Murad, Khaled Elayish(2001), a Program comprehensive archaeological survey of the territory of the Kingdom of Saudi Arabia, the second initial report, survey for South Western Region, Atlal,Yearbook of archaeology of Saudi Arabia, Fifth issue (1981- 1401), Second Edition (20011422).

5- David Graf, Abdul Karim Al-Ghamdi, Def Alla Ettalhi, Saeed Al - Otaibi, Thomas Lestin, 
William Glanzmann, Gary Rawlsen, JeanLouis Ravard, Stephen Seedbotham, Robert Chic, Salem bin Tiran, Hadi Alfaifi, Khaled AlHaiti, Saeed Al-Qarni(2008), The first report on Jurash excavations, Mission US-Saudi joint archaeological, The first season (2008- 1428), Atlal ,Yearbook of archaeology of Saudi Arabia, Twenty - Second Issue( 2012- 1433).

\section{English references:}

1- Benedetti, M. M., Cordova, C. E., \& Beach, T. (2011). Soils, sediments, and geoarchaeology: Introduction.Catena, 85,83-86.

2- Briassoulis, H. (2000). Environmental impacts of tourism: A framework for analysis and evaluation. Tourism and the Environment. Springer.

3- Butzer, W. K. (1982). Archaeology as human ecology. Cambridge: University Press.

4- Butzer, W.K., Butzer, E., \&Love, S. (2013). Urban geoarchaeology and environmental history at the Lost City of the Pyramids, Giza: Synthesis and review. Journal of Archaeological Science, 40(8),3340-3366.

5- Canti, M., \& Huisman, J. D. (2015). Scientific advances in geoarchaeology during the last twenty years. Journal of Archaeological Science, 56, 96- 108 .

6- Rebeca Tallón -Armada, Manuela Costa -Casais, Ramón Blanco-Chao, Teresa Taboada Rodríguez, and Antonio Martínez -Cortizas (2017), Paleoenvironmental reconstruction of an urban archaeological site: The Roman Salt mines of Vigo northwest Iberia, Geoarchaeology;33: pp.112-126.

7- R. Lee Lyman (2017), Paleoenvironmental Reconstruction from Faunal Remains: Ecological Basics and Analytical Assumptions, Journal of Archaeological Research, 25, pp.315-371.

8-Clément Flaux, Mena El-Assal, Nick Marriner,
Christophe Morhange, Jean-Marie Rouchy, Ingeborg Soulié-Märsche, Magdy Torab (2012) Environmental changes in the Maryut lagoon (northwestern Nile delta) during the last 2000 years, Journal of Archaeological Science 39, p. 3493-3504.

9- Clément Flaux, Nick Marrinerb, Mena el-Assal, David Kaniewskia, Christophe Morhange(2017) "Late Holocene erosion of the Canopic promontory (Nile Delta, Egypt)", Marine Geology, Volume 385, pp. 56-67.

10- Farnaz Sedghy, Abdol-Reza Varasteh, Mojtaba Sankian, Malihe Moghadam, Interaction Between Air Pollutants and Pollen Grains: The Role on the Rising Trend in Allergy, Reports of Biochemistry \& Molecular Biology, Vol.6, No.2, Apr 2018.

11- Ingrida Šaulienè, Laura Veriankaite, Analysis of high allergenicity airborne pollen dispersion: common ragweed study case in Lithuania, Annals of Agricultural and Environmental Medicine 2012, Vol 19, No 3, 415-419.

12- Josuah Tremblay, Martin Lavoie, and Najat Bhiry (2019) Paleoenvironmental reconstruction of abandoned meanders in the Assumptions River, Québec (Canada), Geophysical Research, Vol. 21, EGU2019-12120.

13- Heritage, S.C.F.T.N. (2015). (Integration) success story in human resources development and localization of tourism professions. Saudi Arabia: General authority for tourism and national heritage.

14- H. Tronchere, B.Millet, J.- P. Goiran, P. Carbonel, H. Djerbi, R. Vera, M. Torab, M. Elassal and Y. Callot (2012) Geoarchaeological results from the harbor of Taposiris and implications concerning the construction of the harbor, $\ddot{A}$ gypten und Levante/Egypt and the Levant 22, pp. 383-394.

15- Morhange, Christophe. Bony, Guénaelle. 
Elassal, Mena. Flaux, Clément. Goiran, JeanPhilippe. Marriner, Nick. Torab, Magdy. (2010) Bioindicators and ancient harbour geoarchaeology in the mediterranean: Evidence from the Egyptian coast. Journal of Earth Science, 21.

16- N. Combourieu-Nebout, O. Peyron, V. BoutRoumazeilles, S. Goring, I. Dormoy, S. Joannin, L. Sadori, G. Siani, and M. Mangy, (2013), Holocene vegetation and climate changes in the central Mediterranean inferred from a highresolution marine pollen record (Adriatic Sea), Climate of the Past, of the European Geosciences Union.

17- Nicoll, K., \& Murphy, R. L. (2014). Soil and sediment archives of ancient landscapes, paleoenvironments, and archaeological site formation processes. Quaternary International, 342, pp.1-4.

18- Richard Wartenburger (2010), Paleoenvironmental Reconstruction from Lake Sediments of Lago C'astor, North Patagonian Andes, Master's thesis, Faculty of Science University of Bern.

19- Seddon, P.J. \& Khoja, A.R. (2003). Saudi Arabian tourism patterns and attitudes. Annals of Tourism Research, 30(4), 957-959. 